\title{
Studi Kandungan Fitokimia Ekstrak Etanol Daun Gambir Asal Aceh Tenggara Sebagai Anti Diabetes
}

\author{
Vera Viena $^{1 *}$, Muhammad Nizar ${ }^{2}$ \\ ${ }^{1,2}$ Staf Pengajar Prodi Teknik Lingkungan Fakultas Teknik \\ Universitas Serambi Mekkah \\ J1. Tgk Imum LuengBata Batoh Banda Aceh- Indonesia \\ *Koresponden email: veraviena@serambimekkah.ac.id
}

Masuk: 10 Desember 2017

Diterima: 16 Desember 2017

\begin{abstract}
Indonesia is one of tropical countries that rich in natural resources. It has more than a thousand of medicinal plants. This study focused on assessing the potential of phytochemical content gambir leaves from Southeast Aceh as an alternative of antidiabetes through inhibition of alpha amylase enzyme. Steps of research to be conducted consist of: (1) Making dry simplisia from gambir leaves; extraction of gambir leaves by maceration for $2 \times 24$ hours and screening done every 24 hours, and solvent evaporation to obtain the dry extract of gambir; (2) Analysis of phytochemical (phenolic, flavonoid and tannin) content of ethanol extract of gambir leaves; and (3) Analysis of chemical components using GC-MS. The results showed that the moisture content of powder gambir leaves was 3,017\%, which is still below the national standard. The ethanol extract contained a rendement of $2,47 \mathrm{gr} / \mathrm{gr}$ of dry weight. The inhibition activity of alpha amylase enzyme was obtained at a sample concentration of $1000 \mathrm{ppm}$, e.i $88.22 \%$. The more active a sample in inhibiting the action of the alpha-amylase enzyme, the less the 3-amino-5-nitrosalisilic acid formed in the second stage of enzyme activation. The results of phytochemicalanalysis of ethanol extract of gambir leaves from Southeast Aceh showed secondary metabolite content such as Total Phenolic, Total Flavonoid, and Tanin respectively of 71,$80 ; 32,06$ and $58.39 \%$. The chemical components, e.i the total phenolics, flavonoids and tannins have been reported to have antidiabetic activity by lowering blood sugar levels after inhibition testing via the alpha amylase enzyme.
\end{abstract}

Keywords: ethanol extract of gambir leaves, rendement, alpha amilase inhibition, antidiabetes

Abstrak. Indonesia merupakan salah satu negara beriklim tropis yang kaya akan sumber daya alam, dan memiliki lebih dari seribu tanaman obat. Penelitian ini difokuskan untuk menilai potensi kandungan fitokimiadaun gambir asal Aceh Tenggara sebagai alternatif antidiabetes melalui inhibisi enzim alfa amilase. Tahapan penelitian yang akan dilakukan terdiri atas: (1) Pembuatan simplisia kering daun gambir; ekstraksi daun gambir secara maserasi selama $2 \times 24$ jam dan penyaringan dilakukan setiap 24 jam, serta penguapan pelarut untuk memperoleh ekstrak kering gambir; (2) Analisis kandungan fitokimia (fenolik, flavonoid dan tannin) dari ekstrak etanol daun gambir; dan (3) Analisis komponen kimia menggunakan GC-MS. Hasil uji menunjukkan kadar air serbuk daun gambir sebesar 3,017 $\%$, yang masih dibawah standar nasional. Ekstrak etanol mengandung kadar rendemen sebesar 2,47 gr/gr berat kering.Presentase aktivitas inhibisi enzim alfa amilase diperoleh sebesar 88,22 \% pada konsentrasi sampel $1000 \mathrm{ppm}$. Semakin aktif suatu sampel dalam menghambat kerja enzim alfa amilase, semakin sedikit asam 3-amino-5-nitrosalisilat yang terbentuk pada tahap kedua aktivasi enzim. Hasil uji fitokimia ekstrak etanol daun gambir asal Aceh Tenggara menunjukkan kandungan metabolit sekunder seperti Total Fenolik, Total flavonoid, dan Tanin secara berturut-turut sebesar 71, 80; 32, 06 dan 58,39 \%. Ketiga komponen kimia, yaitu total fenolik, flavonoid dan tanin telah dilaporkan memiliki aktivitas antidiabetes dengan menurunkan kadar gula darah setelah dilakukan uji inhibisi melalui enzim alfa amilase.

Kata kunci: ekstrak etanol daun gambir, rendemen, inhibisi enzim alfa amilase, antidiabetes 


\section{Pendahuluan}

Indonesia merupakan salah satu negara beriklim tropis yang kaya akan sumber daya alam, dan memiliki lebih dari seribu tanaman obat. Pemanfaatan sumber daya alam berupa tanaman obat sebagai obat tradisional untuk menyembuhkan berbagai penyakit telah dilakukan sejak ribuan tahun yang lalu. Saat ini, penggunaan tanaman obat (obat herbal) semakin meningkat. Beberapa obat herbal telah dibuktikan efektif menyembuhkan berbagai penyakit serta dapat dijadikan sebagai obat alternatif, salah satunya sebagai antidiabetes (Kumar et al. 2011).

Menurut data WHO, Indonesia menempati urutan ke-4 terbesar dalam jumlah penderita diabetes mellitus di dunia. Jumlah penderita ini terus meningkat setiap tahunnya (Diabetes Care, 2011). Oleh karena itu, penelitian-penelitian tentang pencarian sumber daya alam yang dapat dimanfaatkan sebagai alternatif antidiabetes terus dilakukan. Salah satunya adalah dengan memanfaatkan gambir (Uncaria gambir Roxb) sebagai antidiabetes melalui inhibisi enzim $\alpha$-glukosidase dan $\alpha$-amilase.

Species Uncaria gambir Roxb. merupakan salah satu tanaman tahunan penghasil getah penting yang banyak digunakan untuk keperluan Industri maupun farmasi. Gambir (Uncaria gambir (Hunter) Roxb.) merupakan tumbuhan yang tumbuh di kawasan tropis dan digunakan sebagai antidiare dan astringen di Asia (Anggraini et al., 2011). Tumbuhan ini dikenal di Sumatera sebagai gambee, gani, kacu, sontang, gambe, gambie, gambu, gimber, pengilom, dan sepelet. Di Jawa dikenal sebagai santun dan ghambhir. Di Kalimantan dikenal sebagai gamelo, gambit, game, gambiri, gata dan gaber. Di Nusa Tenggara dikenal sebagai Tagambe, gembele, gamelo, gambit, gambe, gambiri, gata dan gaber. Di Maluku dikenal sebagai kampir, kambir, ngamir, gamer, gabi, tagabere, gabere,gaber dan gambe (Aisman, 1999).

Di Indonesia tanaman gambir banyak terdapat diberbagai wilayah, diantaranya Sumatra Barat dan Riau, kedua wilayah ini meruapakan wilayah produksi gambir yang telah memasuki pasaran ekspor, sedangkan wilayah Sumatra Utara, Bengkulu, Sumatra Selatan dan Aceh jumlah produksinya masih hanya untuk memenuhi kebutuhan pasar lokal saja. Khusus di daerah Aceh tanaman gambir sangat sedikit, kemungkinan hal ini terjadi karena keterbatasan pengetahuan masyarakat tentang manfaat dan cara pengolahan tanaman gambir (Sabarni, 2015). Tanaman gambir di Aceh terpusat di Kabupaten Aceh Tenggara, kecamatan Darul Hasanah dengan luas areal lebih kurang $200 \mathrm{Ha}$. Sentra produksi berada di desa Kute Panjang, Istiqamah dengan metode produksi cara basah.

Produk gambir dapat dihasilkan dari tanaman gambir dengan cara mengolah daun dan ranting muda menggunakan air panas, dilanjutkan dengan pengepresan, pengendapancairan, danpengeringan bagian endapan, hingga diperoleh produk gambir (Pambayun et al., 2001). Kandungan kimia dari gambir adalah katekin, kuersetin, tannin, lendir, lemak dan malam. Gambir memiliki sifat khas pahit dan kelat (Utami et al, 2008). Beberapa penelitian telah membuktikan bahwa gambir memiliki aktivitas antioksidan yang sangat baik. Senyawa antioksidan memiliki potensi sebagai antidiabetes yang mampu mencegah terjadinya oksidasi glukosa dalam darah. Trina et al.(2014) menyatakan bahwa tumbuhan yang kaya akan tanin memiliki aktivitas antioksidan dan antidiabetes yang baik. Sampai saat ini, peneliti belum menemukan jurnal atau penelitian tentang potensi daun gambir sebagai antidiabetes, oleh karena itu,penelitian ini difokuskan untuk menilai potensi kandungan fitokimiadaun gambir asal Aceh Tenggara sebagai alternatif antidiabetes melalui inhibisi enzim alfa amilase.

\section{Bahan dan Metode}

Sampel daun gambir berasal dari Kute Panjang, Istiqamah, Kec. Darul Hasanah, Aceh Tenggara; etanol p.a; aquadest; aquabidest; buffer fospat, buffer natrium dan $\mathrm{NaOH}$.

Adapun alat-alat yang digunakan dalam penelitian ini adalah pisau stainless steel, sarung tangan, blender Miyako, erlenmeyer Pyrex, corong pisah Owako, timbangan digital Ohaus, Oven Memert, Filter Paper Whatman, rotary evaporator Eyela, microplate reader, GC-MS Shimadzu.

\subsection{Persiapan Bahan Baku}

Daun segar gambir asal Aceh Tenggara dipilih 
khusus yang tua, lalu dicuci dengan air mengalir dan dikering anginkan selama 1 minggu. Selanjutnya dikeringkan dalam oven pada suhu $40^{\circ} \mathrm{C}$, kemudian dihaluskan (AOAC, 1984). Serbuk daun gambir kering selanjutnya dianalisa kandungan air, rendemen dan digunakan untuk ekstraksi etanol.

\subsection{Ekstraksi}

Ekstraksi sampel dengan teknik maserasi dilakukan menggunakan metode standar Kemenkes RI (2009). Masing-masing sampel ditimbang sebanyak 500 gram, ditambahkan pelarut etanol p.a 1:10, didiamkan $2 \times 24$ jam, penyaringan dilakukan setiap 24 jam, maserat direndam kembali dengan jumlah dan jenis pelarut yang sama. Filtrat yang diperoleh dipekatkan dengan penguap putar, sehingga diperoleh ekstrak pekat atau kering.

\subsection{Uji Aktivitas enzim alfa amilase}

Larutan enzim $\alpha$-amilase yang digunakan adalah enzim porcine pancreatic amilase 1 unit $/ \mathrm{ml}$. Reagen yang diperlukan adalah buffer natrium fosfat $20 \mathrm{mM}$ dengan $\mathrm{pH} 6,9$. substrat yang digunakan adalah larutan pati soluble $1 \%$. Reagen warna yang digunakan adalah campuran larutan natrium kalium tartarat dengan larutan asam 3,5-dinitrosalisilat $96 \mathrm{mM}$.

Campuran reaksi dibuat dengan melarutkan $125 \mu 1$ larutan sampel dan $125 \mu l$ larutan enzim. Setelah campuran reaksi diinkubasi pada suhu $37^{\circ} \mathrm{C}$ selama 10 menit, larutan pati ditambahkan sebanyak $125 \mu \mathrm{l}$ dan diinkubasi kembali pada suhu 37o C selama 10 menit. Setelah inkubasi kedua, pereaksi DNS ditambahkan sebanyak $500 \mu \mathrm{l}$ dan diinkubasi kembali selama 5 menit pada air mendidih. Setelah itu, $5 \mathrm{ml}$ air suling ditambahkan dan diukur absorbansinya pada panjang gelombang $540 \mathrm{~nm}$. Kontrol positif yang digunakan pada penelitian ini adalah acarbose $0.5 \mathrm{mg} / \mathrm{ml}$ yang diperoleh dari pelarutan 1 tablet glukobay dalam $100 \mathrm{ml} \mathrm{HCl} 2 \mathrm{~N}$. Tabel 1 . menunjukkan kombinasi jumlah sampel, buffer 13 fosfat, dan enzim yang diberikan pada balnko, kontrol A, kontrol B, sampel serta acarbose sebagai kontrol positif.

Blanko digunakan untuk mengukur jumlah gula awal yang telah terdapat pada pati, sedangkan kontrol A digunakan untuk mengukur jumlah gula yang telah terhidrolisis pada pati. Kontrol B digunakan untuk mengukur jumlah gula awal pada sampel dan pati, sedangkan sampel digunakan untuk menghitung jumlah gula yang telah terhidrolisis pada sampel dan pati.

Setiap pengujian diulang sebanyak 3 kali. Masing-masing pengujian daya hambat ekstrak terhadap aktivitas $\alpha$-glukosidase dihitung dalam $\%$ inhibisi dengan rumus,

$$
\% \text { inhibisi }=\frac{\mathrm{C}-\mathrm{S}}{\mathrm{C}} \times 100 \%
$$

$\mathrm{C}$ adalah absorbans larutan tanpa adanya ekstrak (kontrol) dan S adalah absorbans larutan dengan pemberian ekstrak dari sampel. Nilai $\mathrm{IC}_{50}$ diperoleh dengan memplot log konsentrasi versus persen inhibisi menggunakan persamaan regresi. Nilai $\mathrm{IC}_{50}$ adalah nilai konsentrasi yang menghambat $50 \%$ kerja enzim.

\subsection{Analisis fitokimia}

\subsubsection{Total Fenolik}

Sebanyak $0.2 \mathrm{~mL}$ ekstrak sampel dengan konsentrasi $300 \mu \mathrm{g} / \mathrm{mL}, 2.5 \mathrm{~mL}$ reagen FolinCiocalteu $10 \% \mathrm{v} / \mathrm{v}$, dan $2 \mathrm{~mL} \quad \mathrm{Na}_{2} \mathrm{CO}_{3} 7.5 \%$ v/v dicampurkan, lalu diinkubasi selama 15 menit pada suhu $45^{\circ} \mathrm{C}$. Absorban larutan diukur menggunakan spektofotometer pada panjang gelombang $765 \mathrm{~nm}$. Total fenolik ekstrak sampel dinyatakan sebagai miligram $(\mathrm{mg}$ ) asam galat ekuivalen per gram bobot ekstrak kering ( $\mathrm{mg} / \mathrm{g})$. Sebagai standar digunakan asam galat pada berbagai konsentrasi $(0,30,50,70,90,110,130$ $\mu \mathrm{g} / \mathrm{mL})$.

\subsubsection{Total Flavonoid}

Sebanyak $5 \mathrm{~mL}$ ekstrak sampel dengan konsentrasi $500 \mu \mathrm{g} / \mathrm{mL}, 0.3 \mathrm{~mL}$ NaNO2 5\% $\mathrm{v} / \mathrm{v}$, dan $0.3 \mathrm{~mL} \mathrm{AlCl3} \mathrm{10 \%} \mathrm{v/v} \mathrm{dicampurkan}$ lalu diinkubasi selama 5 menit. Kemudian ditambahkan $2 \mathrm{~mL} \mathrm{NaOH} 1 \mathrm{M}$. Absorban larutan diukur pada panjang gelombang $510 \mathrm{~nm}$ dan total flavonoid ekstrak sampel dinyatakan sebagai milligram (mg) ekuivalen katekin per gram ekstrak kering $(\mathrm{mg} / \mathrm{g})$. Sebagai standar digunakan katekin pada berbagai konsentrasi $(0,10,20,40$, $60,800,100 \mu \mathrm{g} / \mathrm{mL})$.

\subsubsection{Total Tanin}


Kandungan total tanin ditentukan dengan metode Chanwitheesuk et al. (2005) yang sedikit dimodifikasi. Sebanyak 0,5 g sampel diekstraksi dengan $10 \mathrm{~mL}$ dietil eter selama 20 jam, kemudian disaring dan residu yang diperoleh dididihkan dengan $100 \mathrm{~mL}$ akuades selama 2 jam, kemudian didinginkan dan disaring. Ekstrak yang diperoleh ditambahkan dengan akuades hingga volume ekstrak $100 \mathrm{~mL}$. Sebanyak 0,1 mL ekstrak ditambahkan dengan $0,1 \mathrm{~mL}$ reagen Folin Ciocalteu dan divortex, ditambahkan dengan 2 $\mathrm{mL} \mathrm{Na}_{2} \mathrm{CO}_{3}$. Diukur Absorbansi pada $\lambda 760 \mathrm{~nm}$ setelah diinkubasi selama 30 menit pada suhu kamar. Hasil yang diperoleh diplotkan terhadap kurva standar asam tanat yang dipersiapkan dengan cara yang sama. Kandungan total tanin dinyatakan dalam mg asam tanat/kg ektrak.

\subsection{Analisis GC-MS}

Ekstrak etanol sampel daun gambir dianalisis komponen organik didalamnya menggunakan Gas Chromatography-Mass Spectra (GC-MS).

\section{Hasil dan Pembahasan}

Penelitian ini bertujuan untuk mengkaji kandungan fitokimia daun gambir dengan menilai efektivitas inhibitor $\alpha$-amilase dari ekstrak etanol daun tersebut. Tahapan penelitian yang akan dilakukan terdiri atas: (1) Pembuatan simplisia kering daun gambir, ekstraksi daun gambir secara maserasi, serta penguapan pelarut untuk memperoleh ekstrak kering gambir; (2) Analisis kandungan fitokimia (fenolik, flavonoid dan tannin) dari ekstrak etanol daun gambir; dan(3) Analisis komponen kimia menggunakan GC-MS

\subsection{Analisis kadar air}

Analisis kadar air bertujuan untuk menghitung kandungan air yang bebas dan terikat dalam suatu bahan, dan untuk mengetahui lama masa penyimpanan bahan terhadap daya tahan terhadap mikroba. Pada penelitian ini dilakukan analisa kadar air pada daun kering gambir yang telah dihancurkan menjadi serbuk. Pada Tabel 1 ditabulasikan hasil analisa kadar air serbuk daun gambir dengan nilai rerata diambil dari tiga kali pengulangan.

\subsection{Analisis hasil ekstraksi}

Ekstraksi serbuk daun gambir dilakukan dengan metode ekstrak cair-cair dengan maserasi selama 2 x 24 jam. Maserasi merupakan matode ekstraksi dengancara merendam sampel menggunakan pelarut yang sesuai dalam jangka waktu tertentu. Metode ini dapat berlaku untuk ekstraksi kompenen bahan alam yang tidak tahan terhadap perubahan suhu tinggi atau terhadap pemanasan, sehingga dapat menghindari kerusakan komponen kimianya. Analisa hasil rendemen dihitung setelah proses rotari evaporator untuk menghilangkan kandungan zat pelarut etanol. Hasil analisa rendemen ekstrak etanol gambir setelah proses pemekatan dengan rotari evaporator ditabulasikan dalam Tabel 2.

Rendemen ekstrak etanol serbuk gambir diperoleh sebesar 2,847 gram per gram berat kering daun gambir. Pelarut etanol yang digunakan dalam penelitian ini mampu mengekstrak seluruh komponen kimia, terutama tannin dan flavonoid didalam bahan karena adanya perbedaan konsentrasi larutan di dalam dan di luar jaringan. Berdasarkan Harborne (1987), etanol termasuk dalam golongan alkohol yang digunakan untuk ekstraksi tanaman secara keseluruhan.

Tabel 1. Kadar air serbuk daun gambir

\begin{tabular}{ccccc}
\hline Ulangan & $\begin{array}{c}\text { Bobot cawan } \\
\text { kosong (gram) }\end{array}$ & $\begin{array}{c}\text { Bobot sampel } \\
\text { awal (gram) }\end{array}$ & $\begin{array}{c}\text { Bobot cawan }+ \\
\text { sampel kering } \\
\text { (gram) }\end{array}$ & Kadar air \\
\hline 1 & 3,10 & 3,00 & 6,01 & 3,01 \\
2 & 3,07 & 3,08 & 6,05 & 3,02 \\
3 & 3,15 & 3,07 & 6,11 & 3,02 \\
\hline Rerata & & & & 3,017
\end{tabular}


Tabel 2. Hasil analisa rendemen serbuk daun gambir

\begin{tabular}{|c|c|c|c|c|}
\hline $\begin{array}{c}\text { Jenis sampel } \\
\text { gambir }\end{array}$ & & & & $\begin{array}{l}\text { Hasil rendemen } \\
\text { (gram, b/b } \\
\text { kering) }\end{array}$ \\
\hline $\begin{array}{l}\text { Daun gambir } \\
\text { (DG) }\end{array}$ & 2,98 & 2,89 & 2,69 & 2,847 \\
\hline
\end{tabular}

\subsection{Inhibisi Enzim Alfa Amilase}

Kerja enzim $\alpha$-amilase pada molekul amilosa meliputi dua tahap. Pertama, degradasi amilosa menjadi maltotriosa yang terjadi secara acak. Degradasi terjadi sangat cepat yang diikuti dengan penurunan viskositas yang cepat pula. Pada tahap akhir terjadi pembentukan glukosa dan maltosa. Proses ini berlangsung dengan sangat lambat dan terjadi secara tidak acak. Sedangkan hidrolisa enzim $\alpha$-amilase pada molekul amilopektin akan menghasilkan glukosa, maltosa, dan berbagai jenis $\alpha$-limit dekstrin yaitu oligosakarida yang terdiri dari empat atau lebih residu gula yang semuanya mengandung ikatan $\alpha-1,6$ (Winarno 1980). Pada Grafik 1. Ditampilkan hasil uji aktivitas inhibisi enzim alfa amilase pada ekstrak etanol gambir asal Aceh Tenggara.

Ektrak etanol daun gambir menunjukkan aktivitas inhibisi alfa amilase yang tinggi dikarenakan kandungan kimia metabolit skunder fenolik yang berfungsi sebagai antioksidan tertinggi yang dapat menghambat enzim alfa amilase. Presentase inhibisi enzim alfa amilase diperoleh sebesar 88,22 \% pada konsentrasi sampel $1000 \mathrm{ppm}$. Semakin aktif suatu sampel dalam menghambat kerja enzim alfa amilase, semakin sedikit asam 3-amino-5-nitrosalisilat yang terbentuk pada tahap kedua aktivasi enzim.

\subsection{Analisis Fitokimia}

Hasil ekstraksi etanol daun gambir selanjutnya di uji kandungan fitokimia berupa total fenolik, flavonoid dan tanin, seperti yang ditampilkan pada Tabel 3.

Menurut Isnawati et al (2012), ekstrak Gambir mengandung senyawa fungsional yang termasuk dalam golongan senyawa polifenol dan senyawa

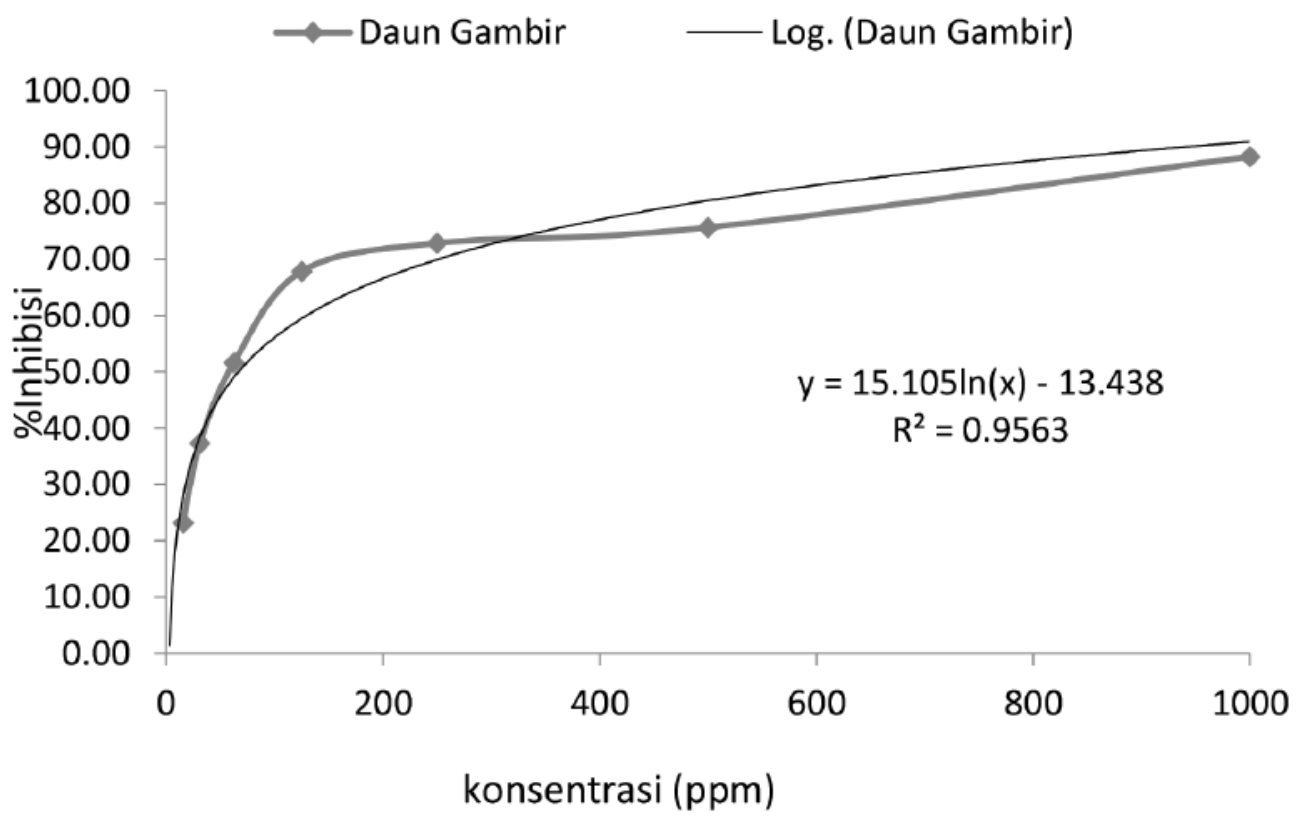

Gambar 1. Aktivitas inhibisi alfa amilase ekstrak etanol daun gambir 
Tabel 3. Kandungan fitokimia serbuk daun gambir

\begin{tabular}{cccc}
\hline Ulangan & Kandungan Fitokimia (\%) & \\
& Total Fenolik & Total flavonoid & Total Tanin \\
\hline U1 & 70,00 & 32,25 & 57,54 \\
U2 & 71,56 & 31,97 & 57,85 \\
U3 & 73,85 & 31,97 & 59,77 \\
\hline Rerata & 71,80 & 32,06 & 58,39
\end{tabular}

ini merupakan hasil metabolit sekunder tanaman yang menyusun golongan tanin. Salah satu yang termasuk dalam senyawa polifenol adalah flavanoid. Katekin merupakan se-nyawa golongan tanin oligomeric procya-nidin (OPC). Secara farmakologi, OPC dan monomernya bersifat seperti flavonoid dan seringkali diklasifikasikan sebagai flavonoid.

Flavonoidmempunyaisifatsebagaiantioksidan, bersifat melindungi timbulnya penyakit jantung dan dapat menurunkan lipidperoksidase serum. Hasil penelitian menyebutkan bahwa coklat yang mengandung flavonoid turunan katekin dan epikatekin dapat menghambat oksidasi kolesterol LDL sebesar $75 \%$. Dari beberapa hasil penelitian, ekstrak Gambir juga mempunyai kemampuan atau berpotensi sebagai antibakteri, antinematoda, tukak lambung, dan hasil infusa Gambir mempunyai efek sebagai perangsang susunan urat syaraf otonom pada hewan coba. Upaya melakukan penelitian karakteristik kualitas mutu terhadap ekstrak tanaman Gambir,yang merupakan tanaman spesifik lokal dan merupakan komoditi ekspor ditujukan untuk meningkatkan pemanfaatannya secara optimal sebagai bahan obat herbal.

Gambir mengandung senyawa metabolit sekunder yang paling dominan yaitu katekin

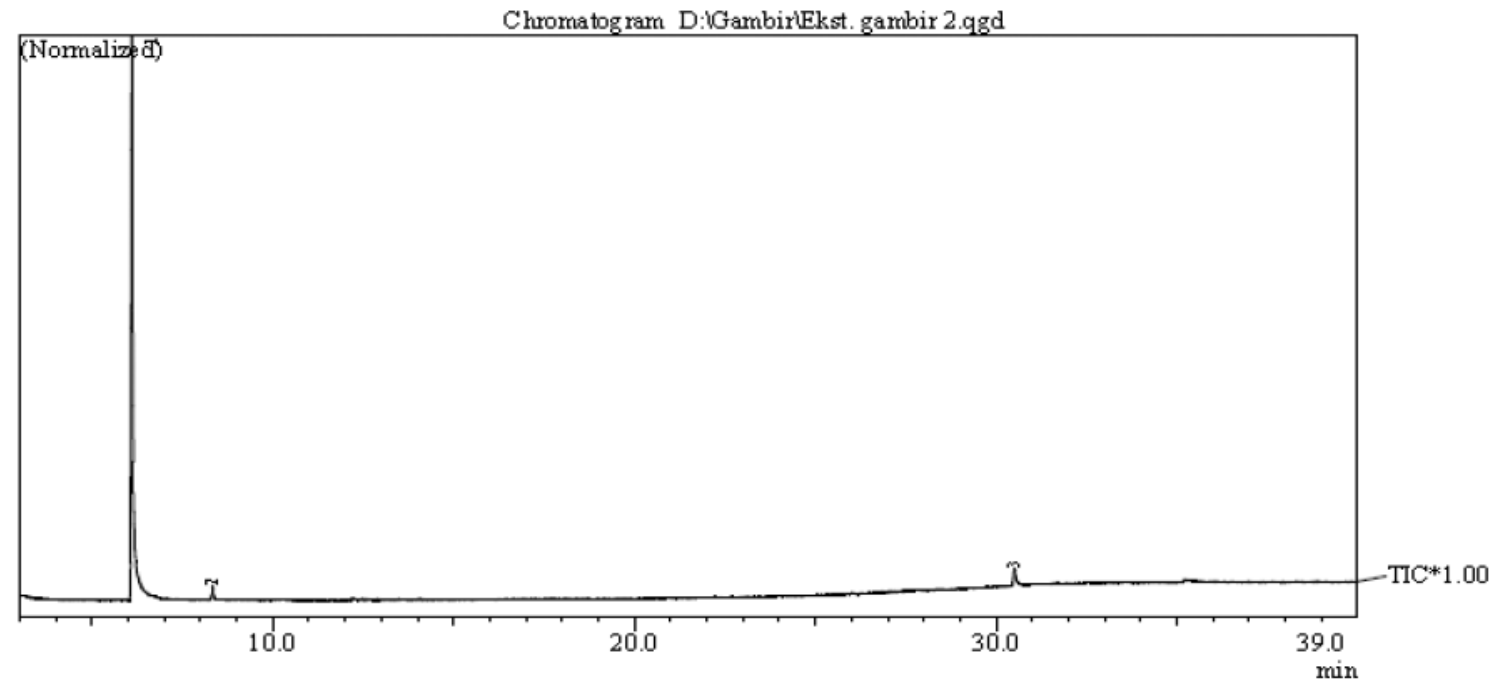

Peak Report TIC

\begin{tabular}{|c|c|c|c|c|}
\hline \multicolumn{2}{|c|}{ Peakitim R. Time } & & & \\
\hline 1 & 6.103 & 1801868 & 94.63 & 2-Pentanone, 4-hydroxy-4-methyl-(CAS) Diacetone alcohol $\$$ \$-PENTANONE, 2-H \\
\hline 2 & 8.334 & 36064 & 1.89 & Hydroperoxide, 1 -methylethyl (CAS) Isopropyl hydroperoxide $\$ \$(\mathrm{CH} 3) 2 \mathrm{CHOOH}$ \\
\hline 3 & 30.507 & 66228 & 3.48 & 1,2,3-Propanetriol (CAS) Glycerol $\$ \$$ Glyrol $\$ \$$ Glycerin $\$ \$$ Osmoglyn $\$ \$$ Glysanin $\$ \$$ Glycen \\
\hline & & 1904160 & 100.0 & \\
\hline
\end{tabular}

Gambar 2. Hasil GC MS ektrak etanol daun gambir. 
dan tanin. Tanin merupakan senyawa fenolik kompleks. Katekin merupakan senyawa turunan dari tanin, yang berupa flavan-3-ol. Senyawa golongan tanin memiliki peran yang sangat baik sebagai antioksidan, sehingga dapat dimanfaatkan sebagai antidiabetes. Tanin dari beberapa tumbuhan telah diteliti memiliki aktivitas antidiabetes yang baik.

Hasil uji fitokimia ekstrak etanol daun gambir asal Aceh Tenggara menunjukkan kandungan metabolit sekunder seperti Total Fenolik, Total flavonoid, dan Tanin secara berturut-turut sebesar 71, 80; 32, 06 dan 58,39 \%. Ketiga komponen kimia, yaitu total fenolik, flavonoid dan tanin telah dilaporkan memiliki aktivitas antidiabetes dengan menurunkan kadar gula darah setelah dilakukan uji inhibisi melalui enzim alfa amilase dan alfa glukosidase. Ketiga fraksi kimia teraktif tersebut telah berfungsi dengan baik sebagai komponen utama antidiabetes alami.

\subsection{Hasil GC MS ekstrak daun gambir}

Untuk mengetahui kandungan bahan organik dalam ekstrak daun gambir asal Aceh Tenggara maka dianalisis komponen didalamnya menggunakan Gas Chromatography-Mass Spectra (GC-MS). Pada Gambar 2 ditampilkan hasil GC MS kandungan ekstrak etanol daun gambir.

Analisa GC-MS menunjukkan adanyan kandungan pentanon hidroksil, hidroperoxide dan propanetriol yang merupakan komponen bahan organik dalam ekstrak etanol gambir.

\section{Kesimpulan dan Saran}

Ekstrak etanol mengandung kadar rendemen sebesar 2,47 gr/gr berat kering. Presentase aktivitas inhibisi enzim alfa amilase diperoleh sebesar 88,22\% pada konsentrasi sampel 1000 ppm. Hasil uji fitokimia ekstrak etanol daun gambir asal Aceh Tenggara menunjukkan kandungan metabolit sekunder seperti Total Fenolik, Total flavonoid, dan Tanin secara berturut-turut sebesar 71, 80; 32,06; dan 58,39 $\%$. Ketiga fraksi kimia teraktif tersebut telah berfungsi dengan baik sebagai komponen utama antidiabetes alami, melalui uji inhibisi enzim alfa amilase yang dilakukan.

Penelitian lanjutan perlu dilakukan untuk menguji aktivitas inhibisi enzim alfa glukosidase dan memurnikan senyawa aktif yang terkandung dalam semua komponen daun, ranting, bunga dan produk gambir asal Aceh Tenggara agar diperoleh aktivitas antidiabetes dalam senyawa teraktif tersebut.

\section{Daftar Pustaka}

Aisman, 1999, Kajian Sosio-Tekno-Ekonomi Komoditi Gambir (Fak.Pertanian; UNAND, Sumatra Barat, Vol 18.

Anggraini T, Tai A, Yoshino T, Itani T. 2011. Antioxidative activity and catechin content of four kinds of Uncaria gambir extracts from West Sumatera, Indonesia. Afr JBiochem Res. 5:33-38.

AOAC. 1984. Official Methods of Analysis. Associat Official Anal Chemist. Washington D.C.

Chanwitheesuk A, Teerawutgulrag A, Rakariyatham N. 2005. Screening of antioxidant activity and antioxidant compounds of some edible plants of Thailand. Food Chemistry. 2005;92:491497.

Diabetes Care. 2011. Diagnosis and Clasification of Diabetes Mellitus. Diabetes care. 34(1). doi: $10.2337 / \mathrm{dc} 11-\mathrm{S} 062$.

Isnawati dkk. 2012. Karakterisasi Tiga Jenis Ekstrak Gambir (Uncaria gambir Roxb) dari Sumatera Barat. Bul. Penelit. Kesehatan. Vol 40. No 4. 201-208

Kemenkes RI. [FHI] Farmakope Herbal Indonesia. 2009. Keputusan Menteri Kesehatan Republik Indonesia Nomor 261/ Menkes/SK/IV/2009 Tentang Farmakope Herbal Edisi Pertama. Jakarta: MENKES RI.

Kumar R, Arora V, Ram V, Bhandari A, Vyas P. 2011. Hypoglicemic and hypolipidemic effect of allopolyherbal formulation in streptozotocin induced diabetes mellitus in rats. Int J Diabet Mell. Xxx: xxx-xxx

Sabarni, 2015, Teknik Pembuatan Gambir (Uncaria gambir Roxb) Secara Tradisional, Journal of Islamic Science and Technology, Vol 1, No.1, 105-112.

Pambayun, R., Hasmeda, M., Saputra, D., dan Suhel (2001).Peningkatan produksi dan perbaikan kualitas gambirToman, Musi Banyu Asin. Laporan Kegiatan ProgramVucer Multi Years, Kerjasama DITBINLITABMASDIKTI melalui 
UNSRI dengan Pemda Musi Banyuasin, Sumatera Selatan. Tidak Dipublikasikan.

Harborne, J.B, 1987, Metode Fitokimia: Penuntun Cara Menganalisis Tumbuhan. Padmawinata K. Soediro I, Penerjemah. Bandung; ITB Pr. Terjemahan dari: Phytochemical Methods.

Trina, Fitnawati, Sofiyanti N. 2014. Identifikasi tumbuhan antidiabetes berdasarkan analisis kuantitatif asam tanat. JOM FMIPA. 1(2): 409-416.

Utami, P., Novi, W., Nina, W., Devi, D., Agung, S., Tinton, D.P., Hadi, I., Lukito, A.M., Ug’t dan Iwan, S., 2008, Buku Pintar Tanaman Obat 431 Jenis Tanaman Penggembpur Aneka Penyakit, Jakarta: PT. Agromedia Pustaka.

Winarno F.G, 1980, Kimia Pangan dan Gizi, Jakarta: Gramedia Pustaka Utama

\section{Ucapan Terima Kasih}

Ucapan terima kasih kepada DRPM KEMENRISTEKDIKTI yang telah membiayai penelitian ini melalui Hibah Dosen Pemula (Kontrak no: 014/K13/A.K.PL/2017). 